\title{
flreuritrhes Steuterbuth.
}

Ein Wegweifer durch die neuen Steuergejez̧e

für jeden preufifithen Staatsbürger

von

Dr. 3. 3aftrow,

Bribatbajent an ber univerjität $\mathfrak{B e r l i n t . ~}$

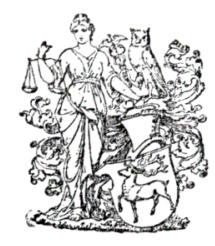

Reipzin,

Berlag von E. R. Şiriffeld.

1894. 
Nadionaf unteriagt. 